The Brock Review Volume 11 No. 1 (2010)

(C) Brock University

\title{
Canadian Architecture and Nationalism: From Vernacular to Deco
}

\author{
Alla Myzelev \\ University of Guelph
}

\begin{abstract}
The debates about national and local architecture in Canada go as far as the construction of the first permanent structures. The young country had to invent its native architectural tradition and at the same time to mitigate European influences. Introducing the notion of longing - or nostalgia - into the debate on Canadian design and architecture this study argues that European grandeur, innovations as well as financial and cultural magnitude often played an important role in the desire to create artistic projects including public and residential buildings. The interest in the Gothic revival and the forging of the Neo-Gothic style can be tied to a nostalgic feeling for the British Isles (their land of origin) and also for the utopian notions of unalienated artistic production during the Romanesque and Gothic periods championed by British philosophers Augustus Welby Pugin (1812-1852) and John Ruskin (1919-1900). The cultural horizons of those who participated in the forging of the national style included both the notion of modernity and its opposite (the antimodern), the dream of the new but also the dream of the old. The article argues that such a complex inspiration is at the core of any modernist production, for it brings together and blurs the modern and anti-modern, the old and the new, and by doing so, it generates constant innovation. At the core of forging the nationalist style, there is also a desire to incorporate European history and heritage, not to negate or reject it. Finally, it argues that Art Deco became the vehicle that helped to popularize the ideas of modernity propagated by avant-garde artists and architects.
\end{abstract}

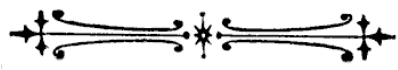

The first forty years of the twentieth century in Canada were marked by constant development and changes in all areas of life, from the military to the political and from the cultural to the linguistic. While in the 1900 s Canada was entering the new century as a dominion influenced by and dependent on England for its political and economic life, by the time World War Two started, Canada had gained both international and national recognition. From the 1940s on, Canada, although still technically a British dominion, became an important force both culturally and politically. It managed not only to free itself from excessive connections with Britain, but also to maintain its national uniqueness from its increasingly more powerful neighbour to the South. ${ }^{1}$ This study will look at the changes that occurred in architectural thought and style in the first thirty years of the twentieth century. Of key importance for the forging of Canadian nationalism in the cultural sphere were the decades of the 1920s and 1930s that brought architecture to a different, more international level. I will argue that these changes were the result of architects' many varied attempts at defining nationalist and modern Canadian architecture.

Among the many cases that illustrate the transformation in understanding architecture and design is the Guild Inn on Toronto's East side. Now the building is a rundown white stuccoed structure waiting for city officials to decide its destiny. In the 1930s and 1940s this large white building was an inviting, bustling, prestigious hotel, boasting some of the best-appointed rooms in 
the area. The story of the hotel's design is emblematic of the architectural development in early twentieth century Canada. The house, or more precisely the manor, was built in Arts and Crafts style in 1914 for Colonel Harold Bickford atop the Scarborough Bluffs. In 1921 it was sold to the Roman Catholic Church's Foreign Mission Society and soon abandoned. In 1932 Rosa and Spencer Clark purchased the building and soon turned it into a hotel. The interior of the hotel bore little resemblance to the exterior because many of the rooms were decorated in modern style with national or local motifs and some of the rooms included lacquered, angular Art Deco furniture. Design and architectural historians rarely address this transformation from Arts and Crafts to Art Deco in design and architecture. This article looks at how this change in views is important in order to understand the proliferation of Art Deco buildings in 1930s and 1940s Canada. The strategies and debates involved in this process parallel debates on national architecture. I argue that Art Deco became the vehicle that helped to popularize the ideas of modernity propagated by avant-garde artists and architects. Art Deco reflected interests in decoration in innovative, often inexpensive materials; in imagery that showcased flora and fauna; and often-nude bodies created architecture that was modernist and popular at the same time. "Modernist" within the framework of this essay is understood as a response to an environment that was changing very rapidly in the early twentieth century. The response to the invention of railways, gas and then the electric light, and changes in the methods of production and consumption of goods, was to look for the style of architecture that would, if not reflect, then at least follow, these innovations. I use "modern" mainly as a descriptive of the style, which, regardless of its particular characteristics, attempted to simplify and streamline neo-gothic and beaux-arts traditions that were prevalent in Canada.

It is important to trace the development of design in Canada in the early twentieth century for a number of reasons. First, changes in architecture and design closely paralleled Canada's cultural and economic development. ${ }^{2}$ Second, an attempt at formulating national characteristics influenced design of the post-World War Two period. By this, I do not mean stylistic idiosyncrasies, but the paradigm of interrelationships between the national and modern and the modernist and the popular. In other words, after World War Two, the idea of functional modern design, austere in ornamentation, continued to be synonymous with national consciousness and pride. This article looks at the complex and varied process of understanding and expressing nationalism in architecture in order to broaden our understanding of modernity to encompass not only stylistic innovation, but also a combination of traditional elements and innovative functions. I argue that Canadian modern architecture of the first thirty years of the twentieth century was modern, not because of its style or the outlook of its creators, but because the search for national expression, which included looking at both British, American and European examples, was a modern phenomenon. Stylistically the buildings mentioned above and the architects discussed were very different, their influences and ideas differed immensely, yet every building that was discussed in the magazines of the time undoubtedly was considering against the idea of forging national architecture. ${ }^{3}$

Canada entered the new century as a country that was just beginning to formulate its own identity. Heavily influenced by the British crown, Canadians spent the first decade of the century trying to link the country from east to west and establish a means of transportation and communication between its remote parts and other continents and to finalize its borders and boundaries. In 1901 Marconi received the first trans-Atlantic wireless message in St. John's, Newfoundland. Furthermore, in 1903 Canada and the US finally established the Alaskan border between the countries. The national railway, which for the first time linked Canada in 1885, became the main, and arguably the only, unifying line between the numerous provinces and identities. The arms-length independence that Britain allowed Canada also encouraged the creation of an independent national identity and organizational system. The process of building the nation between 1900 and1939 was informed by what Ernest Gellner described as "inventing" the nation, a 
phenomenon that offered "opportunities for a select part of the population to consolidate positions of leadership and control by centralizing and streamlining political, economic, and social systems in accordance with its own interests."

Needless to say, architects discussed in this article established and upheld nationalist polemics. Benedict Anderson famously discussed the creation of a nation as the founding of a community that shares a certain system of beliefs, symbols, economic goals, and interior as well as exterior interests. ${ }^{5}$ Subsequent theorists also noted that the nationalist trope had to remain the same, but be adjusted to changing social, political, and cultural circumstances. ${ }^{6}$ Ryan Edwardson calls this process "colony-to-nation phenomenon," a striving to unify people in the war and economic effort, and to bring Canada recognition in the League of Nations in 1919. ${ }^{7}$ The same process also allowed and encouraged wide debate on what it means to have a nationalistic culture and what processes should be in place to start a cultural production that fits into this agenda. It is important to remember that in the forefront of the creation of nationalist identity were people who, as Mary Vipond argues, "were an integral part of a broader English-Canadian elite, formed by both birth and merit, but still an elite of education and position, almost entirely British-Canadian and resident in the major urban centres." " Unlike some artistically inclined intellectuals in Europe who were forging the way for avant-garde movements, Canadian thinkers were neither politically nor culturally radical. As Vipond explains, these people (more correctly men since all of them were) instead aspired for social leadership:

Few of them advocated fundamental social change; they all, however, felt that more rapid change than they had even known before was enveloping them and other Canadians, and believed it to be their duty both to form responses to the new situation and to develop institutions which could cope with it. ${ }^{\text {? }}$

The creation of a national identity took place in a variety of ways. Lorne Pierce promoted adult and children's Canadian literature while in charge of publications at Ryerson Press. ${ }^{10}$ Hugh Eayrs, the president of the British-owned Macmillan, added Canadian authors to the roster of British and American publications. ${ }^{11}$ Vincent Massey, perhaps the best-known philanthropist in Canada, encouraged concerts, festivals and commissioned a concert hall as well as art works. For example, Massey insisted on incorporating lesser-known Canadian works into the repertoire of the Dominion Drama Festival, which he founded in 1932. His agenda of promoting Canadian content was met with resistance by both actors and directors of the festival who preferred more "established international material." "12 In painting, design and architecture the search for nationalism vacillated between complaints on one hand that cultural production was derivative and mainly looked at Europe as an example and being inspired on the other hand by the call to cherish all things Canadian. For example, Toronto artist Marmaduke Matthews lamented that:

within the last few years our Exhibitions have lost a great part of their Canadian or native character. Neither the subjects generally chosen are of home character or interest and even when home scenes and incidents are chosen, in most cases, especially with the more advanced, special pains are taken to assimilate its complexion to that of some foreign model so completely that it is no longer a familiar home scene or incident, but would appeal more tellingly to the public 
for which the European master, on whom the young Canadian is modeling himself, catered. It is hopeless to appeal to Canadians with French songs. ${ }^{13}$

As Matthews rightfully explained, it was unproductive to attempt to create a national style of art, design or architecture by using old European models as examples. Almost unanimously, the artists condemned the influence of continental Europe and approved or accepted as a given similarities between British and Canadian models. On the other hand, J. E. H. MacDonald reminisced about the Group of Seven's influences stemming from club activities and discussions:

The arts league and its annual publications, The Graphic Arts Club with its Canadian evenings, (fellows all singing Sid Howard's canoe songs...), the visiting evenings we used to have at different artists' studios to make half-humourous compositions on Canadian subject [sic] ... there was a ... stirring of Canadian Ideals. ... Reid's City Hall decorations means [sic] much to us... Dave Thomson's drawings in the art league calendars, and his watercolours of Algonquin Park and Scarborough Bluffs were landmarks to us. ${ }^{14}$

The Canadian themes of nature, and familiarity with Canadian artists were the main aspects of artists' training as nationalists. Yet, what art was considered as nationalistic was anybody's guess. Wyly Grier called for nationalist art in the 1913 Arts and Letters Club's Yearbook: "Our art will never hold a commanding position... until we are stirred by our climate; and held to patient and persistent endeavor by the great pioneer spirit which animated the explorers and soldiers of early Canada." 15 The major question for proponents of a national Canadian culture was what exactly constituted a national style.

Canadian participation in the British Empire Exhibition in Wembley (1924-25) exemplifies Canadian ambiguity about its national identity on many levels. While the federal government insisted on presenting Canada as one unified country and "not a Canadian league of provinces," the pavilions presented many local, provincial peculiarities such as local industrial production and agriculture. ${ }^{16}$ Perhaps unsurprisingly, the most independent and most Canadian was the exhibition of paintings, mostly by the Group of Seven. In spite of British audiences' convictions that all the art from the Empire was derivative of the English tradition, Canada presented works asserting that:

Canadian art, whatever the level of its achievement measured against the world's production, is very much alive. Moreover, it seems as if the new leaven was working from inside rather than being, as is so evident in English art, an influence borrowed elsewhere. ${ }^{17}$

Canadian participation showed that the nation had a mixed, and at times, conflicting self-image. Its identity as an independent country was supported by literary and artistic displays while its industrial and business displays showcased strong ties with, and influences from, the Empire. Canadian selfidentification coincided with the advent of international modernism, which helped to a degree to reduce national characteristics. Yet, achieving an independent style in the field of design and architecture was a complicated process since the designers first had to invent one. It is useful here to 
trace a history of thought on the subject of a nationalist style in the nineteenth and early twentieth century. These different, often opposing ideas, allow for an understanding of ideology behind the development of architectural spaces.

William Hay, a Scottish-born architect who lived in Canada from 1847 to the mid-1860s, was one of the first who addressed the issues from both a theoretical and practical point of view. While in Canada he published two articles. One essentially reiterated the doctrines of the British architect A.W.N. Pugin and, therefore, made a Canadian audience familiar with the main postulate of his theory of Gothic revival. The second gave some prescriptions for nationalist architecture. Titled "Architecture for the Meridian of Canada," it argues for adapting a simple, primitive architecture inspired by the notions of French architectural theorist Abbe Laugier. In his Essai sur l'architecture Laugier argues for the abandonment of the richly-decorated Baroque style and a return to the natural function of architecture, namely shelter. ${ }^{18}$ Hay argues that for a rugged and unsettled Canada wooden architecture with very little ornamentation would suit best. ${ }^{19}$ He also cautions us against an overuse of decoration: "trefoils, quatrefoils, cinquefoils, and every other foil which the popular illustrations of ancient or modern Gothic supply, unite with the symbolic triplet window of the altar, in admitting light to the kitchen and pantries within. ${ }^{20}$

Yet towards the end of his essay Hay comes to the surprising conclusion that the "Old English" style is "admirably adapted to the climate in Canada." 21 Pugin's influence is shown in his interest in Gothic. However, perhaps most importantly, Hay treats Canadian architecture as only developing and notes that there are no educational institutions available to artisans. The same situation existed earlier in the century in England. He reminds us that this was "remedied by formation of public museums of ancient models, for the special benefit of artisans." 22 Such models were much needed in Canada, "to correct the depraved taste which is constantly fed by the inventors of such abominations as 'marbleized iron' and 'artificial stone." 23 For Hay, the national style was determined by the severe climate and simplicity of life in Canada or as he called it, the "province." More important is his insistence on the use of the Old English style or English vernacular, which he thought was the most suitable to establish the link between the countries and culture.

In the early twentieth century when the ties of the empire became less necessary for survival and the issue of Canadian identity became one of the most important themes of intellectual debate, a new generation of architects argued for the continuation of the British model of the "Garden City Movement." The sources of the movement, which in North America was propagated by Frederick Law Olmstead, were of the belief that people would be happier and more productive if they lived in healthier environments. Inspired by Jean Jacque Rousseau's call for a natural simplicity of lifestyle and by Pugin's and Ruskin's ideas of healthier and morally sound living, Olmstead argued that "the old work of nature must be considered as simply suggestive of what that [sic] is practicable, suitable, and harmonious with your purposes of large popular use." 24 This passage refers to the development of Mount Royal Park in Montreal, which once completed, Olmstead argued "would be a 'sustained landscape poem." 25 The architect favoured the irregular, picturesque designs that resembled natural British gardens of the eighteenth century. Mount Royal Park showed Canadians a different idea of design, one that had a primary purpose not as an architectural style but rather had moral and practical goals of health and beauty. Olmstead along with supporters of the Garden City movement believed that well-designed and aesthetically pleasing green spaces in the city will elevate morality of the citizens.

Debates in the Canadian architectural press showed that there were three main concerns about architecture in general. Admittedly, none of these explained or addressed the derivative nature of the practice. Instead, British examples were treated as the best and most desirable examples that needed to be adapted and emulated. The first had to do with the increasing speed and shoddiness of construction. Toronto architect Eden Smith lamented: 
Unfortunately for our artistic development we were overtaken here too soon by the same movement as caused an artistic decline in England in our grandfathers' time. We also became able to produce so rapidly, that we had not sufficient time to give thought to our work that is the work necessary to work out artistic theories developed from natural environment. ${ }^{26}$

He referred to the problem raised by A. W. D. Pugin and John Ruskin in England regarding revivalist architecture being cheap and "untruthful." 27 Smith relied on the practice of the Arts and Crafts architects to develop such principles as honesty of materials, purposefulness of the building structures, and the use of the handmade. Following on from these, Smith complained that Canadians in attempting to build quickly on a grand scale had lost sight of quality and workmanship.

The second concern of architects was the return to simplicity. George Agnew Reid, a Toronto architect and painter, claimed that "a return to simplicity and sincerity of intention is the central purpose, and the idea that to insure the production of a beautiful thing the worker must experience a joy and delight in producing it, is coming to be recognized. ${ }^{28}$ Reid not only preached, but also practiced, the return to a simple life. His residence on Indian Road in west-end Toronto was modelled on the English Arts and Crafts cottage. Its architecture and interior design reflected his belief that true architectural beauty could be achieved not by the addition of items but should in fact be the opposite, the refinement of part and the elimination of the unnecessary. "Thus the purest form of art may be a tendency towards economy. Certainly it is opposed to ostentation and pretence." $^{29}$

The third and final concern had to do with "cultivating in the mind of the lay public a higher appreciation for the aesthetic as regards the character of the home surroundings." 30 This education of the public took place through building more houses that closely resembled English cottages. Aside from allowing for harmony, simplicity and economic values, the style functioned additionally as a reminder and proclamation of loyalty to the British Empire.

In the first decade of the twentieth century, Canadian architects and designers wrestled with several important issues, primarily the purpose of architecture and how it reflected the spirit of its age. The influences of schools outside of Canada and the large commissions that were often going to American firms were also important issues. ${ }^{31}$ The style of the era was either Neo-Gothic or British Renaissance, which, F. Reid argued, offered "a logical, practical, and architectural solution of the problem. It presented a dignified and monumental structure." 32 In this passage Reid described the Parliament Buildings in Saskatchewan. However, almost simultaneously, legislative buildings were built in Victoria, Winnipeg, and Edmonton, all in a British-inspired style. It was an artist, Alfred Chapman, who in his 1913 Yearbook of Canadian Art addressed the issue of the stylistic independence of Canadian Architects. He argued that when Canada was a young country unsure of its style it imitated that of the "mother-country." The next unfortunate step, according to Chapman, was the departure from British influence and the subsequent creation of generic, low quality work. In 1913, he argued, Canada positioned itself between two different architectural styles:

The English influence shows the artist a little lost in his problem, but with a keen sense of refinement, while the American influence shows the builder shaping the building to its purpose in a broader and more convincing manner that is almost brutal at times. One seems to be 
striving after abstract beauty, the other after correct logical architecture. ${ }^{33}$

Canadian design in the early twentieth century borrowed intermittently from both English and American architectural traditions with various Neo-Gothic, Neo-Romanesque, and Beaux-Arts styles. Some practitioners raised concerns that what had been produced was too opulent and too similar to the European and mainly British examples; consequently, it exhibited little originality and imagination. The residential architecture was primarily limited to single-house dwellings of various sizes many of which resembled traditional English cottages. The next few pages will look at the temporal and geographical transformation of the cottage-like dwellings in Britain and in Canada.

As Linda Austin convincingly showed in early twentieth century England the cottage became the embodiment of simplicity and a return to living unadulterated by modernity as well as a "national icon." 34 During the Middle Ages cottages were where the servants lived, yet through the eighteenth century the cottage became less symbolic of the social hierarchy and more a picturesque dwelling reminiscent of England's prosperity and beauty. For example, in 1856 Ruskin noted the "marvelous smallness of an English cottage, its simple furniture and swept floors." 35 Austin notes that cottages were sometimes created exactly in the style of the manor and stood "as miniaturized metonym of it, or it could substitute for the great house and serve as a record of public memory." 36 In this sense building cottages and propagating living in cottage-like structures, for instance in Wychwood park suburb in Toronto, which consisted entirely of residential cottages for middle classes and well-to-do-artistically inclined Torontonians, can be seen as a proclamation of loyalty to the mother country and the reinforcement of its superiority. Within an English context, the cottage as an imitation of a manor:

expressed a material and aesthetic connection between the lives inside each building, even as the difference in scale maintained social hierarchy. Especially when situated on the grounds of the estate, the cottage conveyed its original economic relations, that of tenant to landlord, and signified by extension, the territorial or symbolic relation of citizens to fatherland. ${ }^{37}$

Complexes that included both the manor and the cottage, for example Toronto's largest dwelling Casa Loma, designed by Toronto architect E.G. Lennox (1911) for banker and land speculator Henry Pellatt, or Lenwill, Lennox's own residence (1913), existed in early twentieth century Canada. However, much more prevalent and affordable were cottages that stood independently on smaller pieces of land. Both in Britain and in Canada the interest in the cottage had much to do with their aging and changing appearance and status. ${ }^{38}$ English historian Stewart Dick wrote in the early twentieth century that a "yeoman's house of the one generation may serve as the model of the cottar's [sic] dwelling in the next just as we often see the old manor-house actually degraded to the position of a farmhouse as time goes on." 39 It is then not so much the style, age or function that defined what a cottage was, but the signs of decay and its picturesque qualities. ${ }^{40}$ Greenery around the cottage, preferably almost blocking the structure itself, became one of its definitive characteristics. Scottish architect John Claudius Loudon advised building small cottages for farming families against the background of a "wood of oak, or other round-headed trees, to contrast with the upright and angular lines." 41 Richard Elsam in 1816 gave tips on making new structures looking old: "A composition in imitation of brown thatch a few years old or red tiles with a rough surface which 
will soon acquire moss and weather stains." 42 However, all these efforts in making the cottage look old revealed the structures' indexical qualities; in other words, they were supposed to point to a different time and a different place, to evoke a nostalgic feeling for the past.

In a Canadian context the nostalgia that the cottage signified was not for this country's historical past, but for an earlier period of the British Isles. The nostalgia that was created and recreated by Old English architecture served as a link between Canada's present and past. As recent scholarship has shown, nostalgia did not only mean longing for a past that is virtually impossible to return to; nostalgia, which comes from two Greek words, nostros (return home) and algia (longing), is a longing for a home that no longer exists or never existed. ${ }^{43}$ Svetlana Boym argues that "nostalgia is a sentiment of loss and displacement, but it is also a romance with one's own fantasy." eighteenth century nostalgia was considered a disease especially prevalent among soldiers who were serving far away from home: "nostalgia," Boym continues, “operates by an 'associationist magic,' by means of which all aspects of everyday life [relate] to one single obsession." "45 My understanding of nostalgia is rooted in Boym's differentiation between two types of nostalgia: one reflective and the other restorative. Boym shows that nostalgia is an unavoidable human condition that is experienced in the modern world. Restorative nostalgia seeks an impossible return to the past. The reflective nostalgic understands that a return to the past is impossible and, therefore, uses this longing for more constructive purposes such as cultural production.

In spite of the inseparable connection between city cottage living and the continental tradition venerated by centuries, cottage living also signified modernity in the Canadian context. In the United States, Tudor cottages signified simplicity which was often juxtaposed to Queen Anne revivalist styles, which in turn were more elaborate and thus considered more old fashioned. ${ }^{46}$ In Canada, smaller, yet more artistic, houses which were discussed in Construction were stylistically traditional, yet showed less and less applied architectural motifs; gone were elaborated gingerbread ownings and gables, in came minimal brick decoration, larger bay windows, frontal symmetry, and extensive, inviting front porches. The house was supposed to be artistic in terms of its composition, but also answer all the contemporary technical requirements including: double windows and window sashes throughout, double flooring to all floors, basement throughout the area of the building, double roofing, increased heating, hot water system, increased depth of foundation walls. ${ }^{47}$ Canadian Architects and Builder's and later Construction's authors lamented that smaller cottages and houses had very little in the way of style or artistic inclination. The main argument and reason for the overall lack of taste of the construction of budget single-family dwelling was the lack of architects and the use of pattern books. Aside from the journal's interest in propagating the architectural profession, and thus advising hiring an architect, the journal also sang praise to the innovative British Garden Cities and suburbs. ${ }^{48}$ The overall idea that Construction put forward was cooperation between the patron, architect and constructor. Perhaps even more paradoxical was the call for development of larger areas, such as garden suburbs rather than single family dwelling. This emphasis on communal developement supports the ideas of the Harrison mentatility yet also shows influences of the Garden City movement and demonstrates that Canadian architects were interested in the idea of urban and suburban planning and realized the importance of holistic planning, yet another modern phenomenon. ${ }^{49}$

Despite European and American influences, Canadians needed to develop an independent school that would reflect the spirit of the time, which as F. Reid argues, was undeniably commercial: "Irresistible in its effect, it sweeps us on in spite of our better judgment, towards a commercialistic architecture which is guided mainly by the mercenary spirit of the present era." 50 This increasing commercialization of life that Reid was noting with a degree of disdain required architecture that would reflect the innovation and a different nature of the age. In 1932 John Lyle argued against what he called "architectural archeology," in other words, the overuse of historical details and motifs 
in buildings. ${ }^{51}$ He was one of the first architects who thought of, and introduced to his practice, a Modernist style, which he poignantly called a "new medicine" that "seems to make the old young, and the young frantic." 52 While defending the style, he also was critical of unconsciously copying it and he called for the creation of a Canadian style:

If Canadian architecture is to be a living, vital force, it must satisfy the spirit of our people and of the times in which we live. While we cannot claim as yet, a distinctive Canadian style, may we hope that this new freedom for the designer will sweep us along towards a national architecture, for there are present in this modern movement, the same great principles of development that held true in the past. ${ }^{53}$

He went on to claim that what was needed was regional ornamentation, which should be sparingly applied to the modern forms of buildings. The local forms should be inspired from "our fauna, flora, bird, animal and marine life." 54 He implemented his convictions in several buildings including Runnymede Public Library in Toronto (1930), a building that combines French-Canadian influences, native imagery, and Ontario materials. ${ }^{55}$ Lyle was not the only one advocating the use of natural and ingenious ornamentation and materials while translating design from traditional to modern. What George Reid and an older generation of Canadian artists and architects disdained-namely a modern, overtly commercial and socially mobile style-became, for architects such as John Lyle (1872-1945), John Young McCarter (1886-1981) and George Colville Nairne (1884-1953), the main vehicle of expression. All three latter architects, John Lyle through his involvement with the banking architecture of Canada, and McCarter and Nairne through, for example, their iconic Art Deco Marine Building in Vancouver, embraced the new architecture of business and mobility. ${ }^{56}$

To illustrate the idea of modern architecture it is useful to compare residential and commercial buildings in Toronto built almost at the same time in the late 1920s: high-rise apartmentbuilding, the Claridge, designed by the architectural firm of Baldwin \& Greene in the style of Venetian Gothic Palazzo and almost simultaneously in 1928-30, the firm also designed the Victory and Concourse Building in Bay Street Canyon, two sixteen and twenty storey speculative office towers. ${ }^{57}$ The commercial towers do not make use of traditional Art Deco setbacks, but instead concentrate on the imaginative and distinctive architectural detail. For the Concourse Building Baldwin \& Green hired J. E. H. MacDonald, by then an established member of the Group of Seven, who also did not shy away from commercial work. For the side facade of the Concourse Building he designed spandrel panels of cast stone with a stylized pattern of pyramidal mountain peaks. These panels were situated between the windows. The arch of the ground floor, Romanesque in proportion, featured classically-inspired foliage. Yet, juxtaposing old and new, the coffers of the arch are filled with mosaics of airplanes and ships depicting historic and modern means of transportation. The semi-circular panel above the door is also finished in mosaic, with a landscape dominated by a flaring sun and crossed by a stylized stream filled with fish. The vertical piers between the windows are justly renowned, with abstract flame-like motifs borrowed from Aboriginal art and executed in colour tiles. Dendy and Kilbourn argue that "the scheme expresses the 1920s admiration for architecture both as a symbol of the period and as a manifestation for its vitality, because architecture manipulated technology into a form that could dominate the natural landscape." 58

While commercial office towers showed enthusiasm for technological progress and advancement of architectural sciences, apartment complex the Claridge designed by the same firm attempted to utilize a whole gamut of architectural, mainly Victorian, elements to create a building that was the pinnacle of luxurious living in Toronto. The entrance is an arched door, flanked by 
Corinthian pilasters decorated with a vine scroll. Ironwork is one of the hallmarks of the building and provides at least a conceptual link to the earlier Benvenuto, known and praised for ironwork. Benvenuto's iron gates were moved to Burton Road by 1927. Behind classically inspired doors the entrance hall was decorated by J.E.H. MacDonald who used various Spanish and Aboriginal motifs such as Moorish arches, geometrically designed and painted beamed ceilings and colourful tiles. The layout of the hall is open and filled with light. The space has no closed solid wall - all the walls include either windows or arches and allow for numerous extensions through windows and hallways. The chandeliers and sconces are created in the Art Deco style. The walls are plastered to remind one of the Southern Native cultures such as Navajo. The ceiling is painted by a known Canadian painter and designer Carl Shaefer, and the zodiac symbols depicted on the ceiling are executed by Thoreau MacDonald (J. E. H.'s son). Similar to other residential buildings that were discussed earlier, the Claridge's modernity and innovation was concentrated on the inside. The exterior, although eclectic and playful in its references to architectural history, projects the utmost luxury and respectability through grey-buff brick in two tones on the two lower floors and the diamond-pattern on the upper floors. The windows are grouped in bays and rows to emphasize domesticity. The boxed bays projecting out and supported by angels remind one of the Venetian castle palazzo while gargoyles on the corners of the building made of lighter stone remind one of the medieval and fairytale influences. Along with the Victory and Concourse building, the Claridge belongs to a new era of Toronto architecture, one that takes into consideration local history, contemporary cultures and non-Western cultures to blend them with traditional historical architecture. The exotic became modern, while modern sometimes still seemed very exotic. The Claridge was praised and advertised as both secure and fireproof, and comfortable and modern, in possession of two electric elevators. Apartments in all three buildings, the Balmoral, the Claridge and the Clarendon, ranged from one to four bedrooms and a separate living room and dining room. Each apartment had a fireplace in the living room, windows facing at least two directions for ventilation and a bathroom with marble shower stalls and tubs. The building had a service staircase since many apartments had a maid's room. There was also a separate servant's block. Additionally, the building provided the convenience of separate exercise rooms, a laundry room, billiard room, miniature golf course, ground floor reception hall for private parties and a restaurant for residents.

Thus, Canadian architecture and design branched out of British models and developed a language that included both national and international components. John Lyle's conservative modernism was stylistically and ideologically very similar to Art Deco. The style reflected nationalistic sensibilities and was created as a reaction to the traditional stronghold and nostalgia for, in this case, not only Britain or Europe, but also pre-modern Canada. What separates Art Deco, or as Martin Grief observed, "Art Decos," from the modernist aspirations of the avant-garde is the lack of conscious disinterest that was propagated by avant-garde artists. As Charlotte and Tim Benton note, Art Deco objects were always unashamedly merged in the commercial world. ${ }^{59}$ Therefore, these objects lent themselves more easily than the more detached and functional modernist designs advocated by Le Corbusier to transferring and transforming ideas of Canadian nationalism and modernity.

Its desire to bridge high and low along with its ability to permeate every sphere of societal life made Canadian Art Deco a truly democratic style. Overt commercialism contributed to Art Deco's popularity and rapid dissemination. Art Deco helped Canadians to construct and reinforce a belief in the benefits of technological progress. It also helped to diffuse traditionalism and adopt a contemporary set of ideas and imagery. The buildings that were erected in the 1920s and 1930s represented Canadian nature and wilderness amidst the overall optimism of the ruling ideology. The squirrel on the Holt Renfrew building in Montreal, for instance, recalled the long Canadian tradition of the fur trade and at the same time obliterated native histories from the official history of 
colonization and development. This process of transforming a feeling of nostalgia from restorative to reflective helped promote Canada as an international and outward looking country. Rather than concentrating on the connection between Britain and Canada, the architects represented the developing sea trade by commemorating it in the bas-reliefs of the Marine Building in Vancouver or the beauty of local nature by depicting trillium flowers on the façade of the Runnymede Library.

Through this discussion I hope to have demonstrated that the word "modern" in relation to architecture has many different meanings. The modernity of the early twentieth century architecture was not in its exterior and interior style but in the set of ideas and meanings that these styles and innovations brought to the forefront of architectural theory and practice. After World War Two architecture influenced by the avant-garde thinking of Le Corbusier and Gropius became highly functional, adaptive to the needs and lifestyles of families. This process of simplification and adaptation of architecture to the needs, budgets and social development of Canadians had started long before the 1940s. Art Deco as a style and as a tool of artistic expression helped to bridge the gap from traditionalism of historicist influences to the avant-garde modernity and in this it became a style that combined both modernity and populism. 


\section{Notes}

1 Kenneth M. Curtis and John E. Carroll, Canadian-American Relations: the Promise and the Challenge (Lexington: Lexington Books, 1984), 37-43. Cf. Andrew H. Malcolm, The Canadians (Toronto: PaperJacks, 1986), 8.

2 Mary Vipond, "The Nationalist Network: English Canada's Intellectuals and Artists in the 1920s," Canadian Review of Studies in Nationalism, Vol. 7 (1980): 32-52. Cf. Christopher Tait, "Brushes, Budgets, and Butter: Canadian Culture and Identity at the British Empire Exhibition, 1924-25," Canada and the British World: Culture, Migration, and Identity, ed. Phillip Buckner and Douglas R. Francis (Vancouver, UBC Press, 2006): 156-60.

${ }^{3}$ This research is mainly based on architectural magazines Canadian Architect and Builder and Construction as well as the Toronto newspaper The Globe.

${ }^{4}$ Ryan Edwardson, Canadian Content: Culture and the Quest for Nationhood (Toronto: University of Toronto Press, 2008$), 6$.

${ }^{5}$ Benedict Anderson, Imagined Communities: Reflections on the Origin and Spread of Nationalism, (London: Verso, 1991).

${ }^{6}$ Eric Hobsbawm, The Invention of Tradition (Cambridge: Cambridge University Press, 1983).

${ }^{7}$ Edwardson, Canadian Content: Culture and the Quest for Nationhood, 6-7.

${ }^{8}$ Vipond, "The Nationalist Network: English Canada's Intellectuals and Artists in the 1920s," 33.

${ }^{9}$ Ibid., 33-34.

${ }^{10}$ Campbell, “'The Real Discoveries and Master-Builders of this Nation': Lorne Pearce of Ryerson Press and Nationalism in Canadian Art,", 174-5.

${ }^{11}$ Edwardson, Canadian Content: Culture and the Quest for Nationhood, 31.

${ }^{12}$ Ibid., 32.

${ }^{13}$ Matthews in Murray, "Why Are Our Artists So Poorly Encouraged?” 175-176.

${ }^{14}$ MacDonald, in Edwardson, Canadian Content: Culture and the Quest for Nationhood, 33.

${ }^{15}$ Hill, The Group of Seven: Art for a Nation, 58.

${ }^{16}$ Tait, "Brushes, Budgets, and Butter: Canadian Culture and Identity at the British Empire Exhibition, 1924-25," 236.

${ }^{17}$ Lee, The Group of Seven: Art for a Nation, 338.

18 1753, illustrated 1755.

${ }^{19}$ Hay, "Architecture for the Meridian of Canada," 254.

${ }^{20}$ Ibid., 254.

${ }^{21}$ Ibid., 254.

22 Ibid., 254-5.

${ }^{23}$ Hay, "Architecture for the Meridian of Canada," 255.

24 Olmstead, Mount Royal, Montreal, 27.

${ }^{25}$ Simmins, Documents in Canadian Architecture, 77.

${ }^{26}$ Smith, "Canadian House Architecture," 97-98.

${ }^{27}$ Ruskin, 1867. Cf. John Ruskin, The Stones of Venice, Vol. 1. London: Smith, Elder, 1867, 381 and Paul Attenbury and Clive Wainright, eds. Pugin: A Gothic Passion. New Haven: Yale University Press, 1994.

${ }^{28}$ Reid, "Applied Art,." 55.

${ }^{29}$ Reid, "Summer Cottage and its Furnishings," 1901, 57.

${ }^{30}$ Construction 1910, 57.

${ }^{31}$ It was the practice to hire American architectural firms for the largest Canadian projects. For example, the Royal Bank of Canada in Montreal (1926-28) was commissioned by the York and Sawyer architectural firm from New York. Canadian firms often associated with American ones received at least part of the design work, for example, The Canadian Bank of Commerce was designed by Darling \&Pearson in collaboration with York \&Sawyer. (Simmins, 147).

${ }^{32}$ F. Reid, The Year Book of Canadian Art, 277-282.

${ }^{33}$ Chapman, The Yearbook of Canadian Art, 265-67.

34 Austin, Nostalgia in Transition, 1780-1917, 126.

${ }^{35}$ Ruskin, Works, 389-90.

${ }^{36}$ Austin, Nostalgia in Transition, 1780-1917, 129.

${ }^{37}$ Austin, Nostalgia in Transition, 1780-1917, 128.

38 For more on the British cottage and its interpretation in Canada see, "Crawley Court, Hampshire, England," Construction 1914, (The Small House, 1914), (Houses Costing from $\$ 2500$ to $\$ 5000,1914$ ) (First International City Planning Conference in Canada, 1914).

${ }^{39}$ Dick, The Cottage Homes of England., 82. 
${ }^{40}$ Here I part ways with Linda Austin, who argues that similar to childhood, what defined the cottage was its function. Austin, however, does not explain what the actual function of an English cottage was but instead concentrates on the signs of decay and the picturesque qualities of the cottage.

${ }^{41}$ Loudon, An Encyclopaedia of Cottage, Farm and Villa Architecture and Furniture, 51.

${ }^{42}$ Richard Elsam. An Essay on Rural Architecture. London: Philanthropic Society, 1803.

${ }^{43}$ Hall, "Cultural Identity and Diaspora," 223-237; Edwards, "The Need for a 'Bit of History': Place and Past in English Identity," 147-155; Hobsbawm, The Invention of Tradition, 1983.

${ }^{44}$ Boym, The Future of Nostalgia, XIII.

${ }^{45}$ Boym, The Future of Nostalgia, 4.

${ }^{46}$ Smeins, Building an American Identity : Pattern Book Homes and Communities, 1870-1900, 56.

${ }^{47}$ Construction, 1914, 92.

${ }^{48}$ Crossman, Architecture in Transition: From Art to Practice 1886-1905, 56.

${ }^{49}$ F. Reid, The Year Book of Canadian Art, 278.

${ }^{50}$ Ibid.

${ }^{51}$ Lyle, "Canadian Decorative Forms," 65.

${ }^{52}$ Ibid., 66.

${ }^{53}$ Ibid.

${ }^{54} \mathrm{Ibid}$.

${ }^{55}$ MacArthur, A Progressive Traditionalist: John M. Lyle, Architect, 24-25.

${ }^{56}$ On Marine Building in Vancouver see Kalman, 1993 and Kalman, History of Canadian Architecture, 1994.

${ }^{57}$ The Balmoral was designed in 1927-28 by S.B. Coon \& Son and the Clarendon in 1927 by Charles B. Dolphin.

${ }^{58}$ Dendy and Kilbourn, Toronto Observed: Its Architecture, Patrons, and History, 217.

${ }^{59}$ Benton and Benton, Art Deco: 1910-1939, 16.

\section{Bibliography}

Anderson, Benedict. Imagined Communities: Reflections on the Origin and Spread of Nationalism. London: Verso, 1991.

Atwood, Margaret. Survival: A Thematic Guide to Canadian Literature. Toronto: McClelland and Stewart, 2004.

Austin, Linda M. Nostalgia in Transition, 1780-1917. Charlottesville and London: University of Virginia Press, 2007.

Benton, Charlotte, Tom Benton and Ghislaine Wood. Art Deco: 1910-1939. Boston, New York, London: Bulfinch Press, 2003.

Boym, Svetlana. The Future of Nostalgia. New York: Basic Books, 2001.

Brown, Douglas W. Eden Smith: Toronto's Arts and Crafts Architect. Mississauga: W. Douglas Brown, 2003.

Brown, R. J. The English Country Cottage. London: Robert Hale, 1979.

Campbell, Sandra. "“The Real Discoveries and Master-Builders of this Nation': Lorne Pearce of Ryerson Press and Nationalism in Canadian Art," edited by Norman Hillmer and Adam Chapnick, Canadas of the Mind: the Making and Unmaking of Canadian Nationalisms in the Twentieth Century, 174-191. Montreal: McGill-Queen's University Press, 2007.

Chapman, A. H. The Yearbook of Canadian Art. Toronto: MacMillan, 1913, 265-67.

Cohen-Rose, Sandra. Northern Deco: Art Deco Architecture in Montreal. Montreal: Corona, 1996. "Crawley Court, Hampshire, England." Construction 7, no. 1 (1914): 17-23.

Crossman, Kelly. Architecture in Transition: From Art to Practice 1886-1905. Kingston: McGill-Queen's University Press, 1987.

Curtis, Kenneth M. and John E. Carroll. Canadian-American Relations: the Promise and the Challenge. Lexington: Lexington Books, 1984. 
Debord, Guy. Society of the Spectacle. rev. ed. Detroit: Black \& Red, 1977.

Dendy, William and William Kilbourn. Toronto Observed: Its Architecture, Patrons, and History. Toronto: Oxford University Press Canada, 1986.

Dick, Stewart. The Cottage Homes of England. London: Edward Arnold, 1909.

Ditchfield P.H. Picturesque English Cottages and their Doorway Gardens. Philadelphia: John Winston, 1905. . Vanishing England. London: Methuen, 1910.

Edwards, Jeanette. "The Need for a 'Bit of History': Place and Past in English Identity," Edited by Nadia Lovell, Locality and Belonging, 147-165. London: Routledge, 1998.

Edwardson, Ryan, Canadian Content: Culture and the Quest for Nationhood. Toronto: University of Toronto Press, 2008.

Elsam, Richard. An Essay on Rural Architecture. London: Philanthropic Society, 1803.

"First International City Planning Conference Held in Canada." Construction 7, no. 6 (1914): 214-16.

Frye, Northorp. "Conclusion to a Literary History of Canada." In The Bush Garden: Essays on the Canadian Imagination, by Northorp Frye." Toronto: Anansi, 1975.

Hall, Stuart. "Cultural Identity and Diaspora," edited by Jonathan Rutherford. Identity: Community, Culture, Difference. London: Lawrence \& Wishart, 1990, 223-237.

Hartzell, Freyja. "The Velvet Touch: Fashion, Furniture, and the Fabric of the Interior," Fashion Theory. Vol. 13, no. 1, (2009): 51-82.

Hay, William. "The Late Mr. Pugin and the Revival of Christian Architecture." Anglo-American Magazine, II (1853): 70-73.

"Architecture for the Meridian of Canada." Anglo-American Magazine, II (1853): 253-55. Hill, Charles. The Group of Seven: Art for a Nation. Toronto: McClelland \& Stewart, 1995.

Hillier, Bevis, i. London: The Herbert Press, 1985.

Hobsbawm, Eric., The Invention of Tradition. Cambridge: Cambridge University Press, 1983.

“Houses Costing from $\$ 2500$ to $\$ 5000$." Construction 7, no. 3 (1914): 91-93.

Gellner, Ernest. Thought and Change. London: Weidenfeld and Nicolson, 1964.

Kalman, Harold D. Exploring V ancouver: Ten Tours of the City and Its Buildings. Vancouver: University of British Columbia Press, 1993.

-. History of Canadian Architecture. Toronto: Oxford University Press, 1994.

Laugier, Marc Antoine. Observations sur l'architecture. Reprint of 1st edition, Farnborough, Hants.: Gregg Press, 1966.

Le Corbusier, The Decorative Art of Today. Cambridge, Mass.: MIT Press, 1987. 1st MIT Press.

Lee, Rupert. "Canadian Pictures at Wembley." Canadian Forum (1924): 338-340.

Loos, Adolf. Ornament and Crime. Innsbruck, 1908; reprint Vienna, 1930.

Lowenthal, David. The Past is a Foreign Country. Cambridge: Cambridge University Press, 1985.

Loudon, John Claudius. An Encyclopaedia of Cottage, Farm and Villa Architecture and Furniture. London:

Longman, Brown, Green, and Longmans, 1883.

Lyle, John. M. "Canadian Decorative Forms." RAIC Journal (1932): 65-66. . "Address by John M. Lyle, 22 February 1929 at the Art Gallery of Ontario", RAIC Journal (1929): 135-36, 163.

MacArthur, Glen. A Progressive Traditionalist: John M. Lyle, Architect. Toronto: Coach House Books, 2009.

Malcolm, Andrew H. The Canadians. Toronto: PaperJacks, 1986.

Martin, Luther H., Gutman Huck and Patrick H. Hutton, eds. $i$ London: Tavistock Publications, 1988. 
Murray, Joan, and Marmaduke Matthews. "Why Are Our Artists So Poorly Encouraged?" Journal of Canadian Studies Vol. 18, no. 4 (1988): 176-180.

Olmstead, Frederick Law. Mount Royal, Montreal. New York: G. P. Putnam’s Sons, 1881, 22-27.

Radstone, Susannah. The Sexual Politics of Time. London, New York: Routledge, 2007.

Reid, F. The Year Book of Canadian Art. Toronto: MacMillan, 1913.

Reid, George A. "Applied Art." The Canadian Architect and Builder Vol. 13 (1900): 55. . "Summer Cottage and its Furnishings." The Canadian Architect and Builder. Vol. 14 (March 1901), 57-58.

"Residential Design in Canada," Construction 3, no. 2 (1910): 56-62.

Ruskin, John. Works, Vol. 6, London, 1913, 389-90.

Simmins, Geoffrey, ed. Documents in Canadian Architecture. Peterborough: Broadview Press, 1992. "The Small House." Construction 7, no. 3 ( 1914): 81-91.

Smeins, Linda E. Building an American Identity : Pattern Book Homes and Communities, 1870-1900. Walnut Creek: AltaMira Press, 1999.

Smith, Eden. "Canadian House Architecture.” Maclean's Magazine. Vol. 25 (1911): 97- 101.

Stauth, G. and Turner, B. "Nostalgia, Postmodernism, and the Critique of Mass Culture." Theory, Culture, and Society, Vol. 5 (1988): 509-26.

Tait, Christopher. "Brushes, Budgets, and Butter: Canadian Culture and Identity at the British Empire Exhibition, 1924-25," edited by Phillip Buckner and Douglas R. Francis, Canada and the British World: Culture, Migration, and Identity. Vancouver, UBC Press, 2006.

Tester, Keith. Life and Times of Postmodernity. London: Routledge, 1993.

Vipond, Mary. "The Nationalist Network: English Canada's Intellectuals and Artists in the 1920s." Canadian Review of Studies in Nationalism. Vol. 7 (1980): 32-52.

Wagg, Susan. Percy Erskine Nobbs: Architect, Artist, Craftsman. Montreal: McGill-Queen's Press, 1982. 